\title{
Civics in the Curricular Construction of the Loyal National Citizen: A Comparative View of Switzerland
}

\author{
Rebekka Horlacher \\ University of Zurich, Institute of Education
}

\section{Abstract}

The implementation of public schooling is usually understood as both an expression and a means of nation-building. The formal organization of the school, i.e. the curricula, teaching materials and the respective teacher's education were interpreted as cultural-political arrangements deriving from assumed national convictions about the future of the particular nation-state and its ideal citizens. Against this background, the entire learning arrangement of the curriculum can be seen as an instrument to educate pupils to become loyal national citizens. Of particular interest is the curricular area which is explicitly dedicated to political education, i.e. civics. This paper focuses on precisely this area and its teaching materials on civic education in a nation-state which comprises different nations organized by cantons, which cannot refer to a common religion, history or language and thus to a common culture. Examining two different cantons of Switzerland, this article deals with the question of how nation-building may differ within the framework of one nation-state.

Keywords: history of schooling; nineteenth century; textbooks; nation-building; citizenship education.

\section{Introduction}

The development and implementation of public schooling after the Napoleonic Wars was closely connected to the newly established need of nation-states to implement some sort of "national identity" in the population with the aim of turning former subjects into citizens of a specific nation-state (see Anderson, 1983; Harp, 1989; Schreiber \& Geisler, 2011; Gotling, 2018). The establishment of public and compulsory schooling 
was seen as a reliable means to reach this objective and it was the starting point for the overall success story of modern public schooling (Tröhler, 2011a). Educational expertise was advocated (Fichte, [1808] 2009) and used to (re-)define the nation-state (Horlacher, 2013) and to empower the people to act as moral, social, and economical subjects. Public schooling can thus be understood both as an expression and a means of nation-building (e.g. Tröhler, Popkewitz \& Labaree, 2011; Boser Hofmann, 2017; Westberg, Boser \& Brühwiler, 2019). Moreover, these considerations implicitly assume an idea of the nation as a unit, since the state can be understood as the political organization of a nation, thus being responsible for the corresponding school laws and all school structures based on them. However, this model does not apply to all countries, and certainly not to the case of Switzerland, as Swiss schools have always been organized at cantonal instead of federal level. Although the Federal Constitution of 1874 established nationwide compulsory schooling, concrete organization of the compulsory education was - and still is today - left to the legislation of the individual cantons, which are thus to be regarded as the actual "states" when it comes to schooling and its effects on the empowerment of their future citizens.

Hence, within the political entity of Switzerland - the nation-state - one may examine the question as to what extent different local traditions, i.e. regionally anchored values regarding community and social order, had an impact on the organization of schooling and the design of the according curricula (for specific case studies, see e.g. Criblez \& Hofstetter, 1998; Boser Hofmann \& Dahn-Singh, 2017; Horlacher, 2017). Since these developments took place within one single nation-state (Switzerland), it is to be expected that they aimed at a comparable educational goal which had been shaped by the nation-state and which was superior to the individual cantons and their regional identities. This assumption is supported by the fact that Switzerland, a so-called nation of will (Renan, 1882, p. 19-20), was forced to pay greater attention to citizenship education, since the feeling of being a nation could not be achieved by imposing a common language (as in France or Italy) or invoking a common culture (as in Germany), but had to be kept alive by a "daily referendum", i.e. quite differently (Renan, 1882, p. 26; see Church \& Head, 2013, p. 3).

The institutional expectations can best be conceptualized with the help of curriculum studies, as they understand the school curriculum as a social construct representing what any society judges to be worthwhile knowledge, skills and values for the younger generation (Brady \& Kennedy, 2007). Looking at the diverse planning instruments for teaching as well as their interconnections (Horlacher \& De Vincenti, 2013, p. 476), this framing offers an opportunity to conceptualize different agents in schooling and teaching in their mutual dependency. Thus, schooling means educating future citizens, and the question then arises as to what extent civic education as a special curricular area including the teaching of political structures, democratic living and attitudes, or forms of participation, is seen as important for a specific society in a specific place 
and time, what will be discussed in this article using the example of the two cantons of Vaud and Zurich. The topic leads us back to the beginning of the modern school, which in Switzerland developed in the wake of the July Revolution in 1830, and which also drew on educational reform experiences gained during the Helvetic Republic (1798-1803) (see Horlacher, 2021).

In 1832, the canton of Zurich enacted Switzerland's first comprehensive public education law, which organized schooling on elementary and secondary level. It provided that "children from all classes of the population be educated to become mentally and spiritually active, civically competent, and moral, religious humans" (Gesetz, 1832, $\$ 1$ ). In comparison: the law in the canton of Vaud - a canton differing widely in terms of language, politics and economics, as well as being situated at quite a distance from Zurich - one year later (December 10, 1833) declared quite similarly: "a nation constituted in conformance with the principles of liberty and equality must provide all of its citizens with instruction that is appropriate to their duties and their rights" (Loi, 1833, p. 1). Obviously, the two cantons set themselves quite similar objectives. Yet, Vaud's primary school education act defined one more goal, namely that "ideas about the rights and duties of the citizen" (Loi, 1834, p. 12) are to be taught as one of twelve required school subjects.

Both cantons are considered as "modern" or "advanced" cantons in nineteenthcentury Switzerland, and their populations were primarily or even overwhelmingly Reformed Protestant. However, they differed both historically and linguistically, as Zurich was (Swiss) German speaking, whereas Vaud was French speaking. The citystate of Zurich had been the fifth state to join the Swiss Confederation in the middle of the fourteenth century (1351), whereas the canton of Vaud was only created after the Helvetic Revolution in 1798, and after having been a territory subject to the state of Bern for more than two centuries. Until 1798 (i.e. the outbreak of the Helvetic Revolution), the territory of what is today called Switzerland, had been organized as a loose confederation of largely independent states or cantons (see Church \& Head, 2013). At first this confederation included eight cantons; after 1513 there were thirteen. They pledged neutrality, although many Swiss served as mercenaries in different wars during the Early Modern period. The Swiss Reformation divided the confederation into Protestant and Catholic parties, which caused several internal conflicts and literally paralyzed the federal diet, i.e. the government of the confederation. The cantons themselves were organized in various ways: some were urban states with a dominant city and a surrounding countryside deprived of political rights (e.g. Zurich and Bern), some were more or less democratic rural cantons (e.g. Uri and Glarus), and some were ruled under the joint sovereignty of the entire confederation (e.g. Thurgau and Ticino).

Thus, the two cantons at stake here started out from very different positions when, similar to many other Swiss cantons, they institutionalized statutory public schooling in the early 1830s. Indeed, we find that while the "old" canton of Zurich faced the 
challenge of reshaping its political traditions to meet new conditions, the "new" canton of Vaud faced hurdles in establishing its political identity which was meant to go beyond simply being non-Bernese (i.e. its former rulers). For this reason, both the necessity and the curricular place of civic education were discussed in different ways. Given these differences, the article offers not a classical comparison of two case studies, but focuses in the light of the different political and cultural backgrounds and in the sense of an asymmetrical comparison on the various conceptualizations of educating the future citizens, placing Zurich in the foreground. Thereby, Zurich's difficulties in implementing both, a distinct school subject or an independent school after compulsory schooling is contrasted with the canton of Vaud that from the very beginning of its modern school system had implemented a distinct school subject "civics" and had accordingly produced pertinent textbooks.

With respect to the issue under discussion here, two events in the canton of Zurich are particularly germane and basically represent the two different ways in which the education of future citizens may be designed: either as a specific subject containing particular knowledge, or as an overall topic, being more oriented toward attitudes and values. The first event is the 1842 publication of a book written by one of the "high impact" figures of the Zurich school system, Ignaz Thomas Scherr (1801-1870), titled Die Nothwendigkeit einer vollständigen Organisation der allgemeinen Volksschule (The Necessity of a Comprehensive Organizational System for Public Elementary Schools, 1842). The first part contained an extensive critique of the present school system, as in Scherr's view, the "new public schools" created by the enactment of the Public School Law of 1832 were not capable of fulfilling the expectations placed in them. In the second part, he went on to propose recommendations - a "complete organization" - for the improvement of the schools he had critiqued. The second event is the public debate about the establishment of a separate Zivilschule (civic school) in 1850 and in the late 1860s. This civic school was proposed in response to a partial revision of the constitution of Zurich, which expanded political (democratic) power to the electorate. Following this change, many people questioned whether the citizens, as voters who were now being granted additional power, would be actually capable of responsibly using this power in accordance with the intentions of the democratic and republican constitution of Zurich. Starting out from the debates taking place in Zurich, developments in the education of future citizens in the canton of Vaud will be discussed, serving as a counterfoil to Zurich, and will accordingly be described in less detail. As a newly established canton, the authorities in power felt much more responsible to implement knowledge about political processes and to arouse feelings of political virtue. In the concluding chapter the general idea of the Special Issue is discussed, namely the question of how education promotes national identity and how nation is done by education. It becomes apparent that the differences are not only to be found in the realms of content or ideas, but also in the fact that very different places or organizations are discussed as places of educating future citizens. 


\section{Scherr's model of the lifelong school}

Scherr, who was the son of a teacher from Württemberg, started his teaching career in 1821 at an institute for deaf and blind children in Schwäbisch-Gmünd (Germany) before being offered the job of head teacher at a comparable institute in Zurich, where he made a quick career: in 1831, he was elected member of the Erziehungsrat (education council), a school board on the cantonal level, and in 1832, he became director of the newly established teachers' seminar in Küsnacht. During his career as a member of both Zurich's education council and director of its teachers' seminar, Scherr not only developed extensive teaching materials, but he also published countless papers about schools, the education system, and educational and pedagogical issues in general. He was involved in major disputes along the way, some of which were related to his wide-ranging powers as an education councilor and director of the teachers' seminar, and some of which were an expression of political disputes about the jurisdiction on public schooling. To put it somewhat simply, the issue under debate in the 1830s and 1840s in Zurich was how the canton - and by implication its schools - should be organized politically in the future (see Bluntschli, 1837; Scherr, 1837; Gubler, 1933, p. 218; Tröhler, 2007, p. 58). However, I will not focus on these debates themselves, but only on the second part of the related abovementioned publication The Necessity of a Comprehensive Organizational System for Public Elementary Schools (1842).

This second part follows a biographical-chronological order of age, starting with The School of Childhood (age 6-14), followed by the The School of the Middle Youth defined as "transition from childhood to adulthood" (Scherr, 1842, p. 50), i.e. the age between 14 and 18 (p. 51), and ending with the section The School of the EconomicCivic Age, referring to adults beyond the compulsory school age. This last section is obviously of particular relevance with regard to schools as sites for the education of future citizens. Although it is by far the shortest part in the entire book, consisting of a single page only, it makes a trenchant argument for the topic under discussion here. According to Scherr, the state should offer a "free educational institution" with voluntary attendance specifically intended for young adults (p. 56). These schools were to address contemporary issues in particular, i.e. different aspects of adult people's reallife circumstances. Specific "new laws and regulations [would be] disclosed, explained, discussed ... new discoveries and inventions, important occurrences in current events" would be presented, together with "interesting demonstrations from the natural and geographic sciences" (p. 56-57). In addition, the schools would be charged with producing a monthly publication to be disseminated free of charge to all households in the canton, consisting of "moral," "inspiring" and "entertaining" stories, excerpts of current legislation including explanations, and news stories about agriculture, trade and commerce together with suggestions for improving their organization (p. 57). From this perspective, Scherr's school of economic-civic age is intended to be an overall management of adulthood. 
This school model represented Scherr's antidote to what he viewed as the insufficient training provided in existing public schooling with regard to issues of citizenship education. Scherr understood civic education as going well beyond mere familiarity with laws and regulations to encompass the comprehensive preparation of all adult inhabitants of a state (i.e. canton) to meet their rights and responsibilities as economically productive and morally active individuals, thereby fulfilling the ideal of the republican citizen. According to Scherr, the existing schools failed to live up to this ideal, so he proposed setting up a voluntary school for adults, whose impact should reach all the families living in the canton. While the school he proposed was never implemented, his underlying idea of citizenship education was taken up once again in the 1860 s by the so-called Zurich School Synod. This organization was not simply a teachers' union, but an absolutely unique official and fundamentally democratic teachers' organization unifying teachers and the political authorities in one association (see Tröhler, 2008). The School Synod, which had been established along with the new school law of 1832 in analogy to the Reformed Church Synod, which for centuries had given the Church of Zurich the greatest possible autonomy (Tröhler, 2011b), was therefore an important player in the shaping of public schooling in the canton of Zurich.

\section{The failed attempt to introduce "civic schools" and debates about citizenship education in the Zurich School Synod}

In 1850, the president of the Zurich School Synod, Kaspar Honegger - a secondary teacher and teacher of languages, mathematics and geography at the Zurich Industrieschule (a secondary school focusing on commercial subjects) - and a member of the education council, suggested that it was the mission of the public schools to vindicate the democratic system, as public schooling represented a major "force" in citizenship education, despite its modest means. "Public schooling instills humanity, the common thread running through all real human education, in the heart of each individual, and it is on this fact that I rest my hope that it will become a redemptive and protective force" (Bericht, 1850, p. 11). As is apparent from the remainder of this speech, Honegger was responding to the liberal-democratic revolutions which had taken place throughout Europe in 1848 and 1849. These revolutions were uprisings led by shaky coalitions of reformers, which did not hold together for long. They were based on a widespread dissatisfaction with political authorities, demands for more political participation, demands of the working classes, upsurges of nationalism and the regrouping of the political reactionary forces. The revolutions were more or less concentrated on Central Europe (France, Germany, Poland, Italy, Austria) and forced many political activists into exile, e.g. Germans to Switzerland (Dowe et al., 2000). Although Honegger saw Switzerland threatened by the dangers of internal revolutions, he pointed out that the differences between rich and poor, which had led to such great tensions in other countries, were far less marked in Switzerland. At the same time, 
he expressed hope that Switzerland would have "sufficient wisdom" to "reject the excesses of selfishness," and would possess "sufficient sentiments of self-sacrifice and patriotism so each individual could subordinate personal self-interest to the interests of the nation as a whole, to the degree that they were in opposition" (Bericht, 1850, p. 11). Honegger saw a significant role for the public schools in imparting this social attitude and "educating" citizens to accept it (p. 12).

As noted before, Honegger's focus on the role of public schooling in educating future citizens was motivated by the contemporary revolutions of 1848 and 1849, which had kept half of Europe in suspense. Similarly, but twenty years later, two speeches on the civic education of the youth, delivered once again as parts of the Zurich School Synod, were motivated by events currently taking place inside Switzerland and the canton of Zurich, specifically by the thorough expansion of direct democracy, which was observed with great interest across the Western world (e.g. Lowell, 1895; Macy, 1896; Deploige, 1898). A partial reformulation of the Zurich constitution (1867) introduced the popular initiative - the new constitution provided that 10,000 voters could initiate a vote for a constitutional amendment - and the compulsory referendum, which stipulated that all constitutional amendments and laws passed by parliament would require approval by popular vote before they came into force. Contemporary discussion placed great emphasis on the concern that this new kind of direct democracy by referendum could not be successfully carried out without sufficient civic education (Guggenbühl, as cited in: Frey, 1953, p. 110). Consequently, this constitutional change affected schools directly. At the 1867 School Synod, a today no longer further identifiable secondary school teacher named Wettstein gave a lecture about this issue, to which a school teacher named Frey responded at the same meeting. The two speakers adopted quite different positions; not with respect to the overall aim to strengthen citizenship education, but concerning the ways in which to achieve this goal and the necessity of immediate (school) reforms. Wettstein based his position on the assumption that public discussions about the strengths and weaknesses of public schooling were subject to certain cyclical trends. At the particular moment, Wettstein saw schools as being criticized specifically because "schools were not doing enough for the citizenship education of their pupils," which in his view led to recommendations to establish a program of "civil education" as a "specific third stage in our primary schools" (Wettstein, 1867, p. 1). Wettstein noted that public criticism focused especially on citizens' lack of "political understanding" and "indifference to public matters" (ibid.).

While secondary school teacher Wettstein essentially agreed with this assessment, he claimed that young citizens in particular were often ignorant about their civic responsibilities and would be incapable of exercising their rights. He saw this incapacity as being a consequence of their insufficient instruction in history; the younger generation had not personally experienced the turbulent recent period in Switzerland's history and thus had to be familiarized with the importance of the political advances which had been accomplished, and with the meaning of republican citizenship (p. 2). To meet 
this end, Wettstein asserted that the school curriculum should instill an understanding for the great changes which had occurred in citizens' rights, thereby fostering citizens who regarded the community as a collective enterprise and participated actively in its preservation. Thus, for Wettstein, acquiring knowledge about institutions, something which we might refer to today as "civic education" or "institutional understanding," was a key element in developing an affective connection to the body politic among citizens, and thus in establishing the essential foundation to build a citizen's "feeling" of citizenship as being a responsible part of a specific nation with its intangible values (p. 6).

Comparable to what had been proposed by Scherr a few years earlier, discussions now focused on the option of establishing "civic schools." However, Wettstein expressed doubts that these objectives could be achieved "through a special institution" (p. 8). He justified his skepticism with the legal argument that since the public schools were mandated "to educate children from all classes of the population to become mentally active, civically useful, and morally religious humans," there should be no need to create a separate institution for this purpose. "Competent citizenship cannot be taught; it is the result of a multifaceted, harmonious formation of the individual's intellectual, physical, and spiritual powers" (p. 9). Even if certain areas of knowledge might be required specifically for this purpose, Wettstein noted, they would be nowhere near adequate to shape a "genuine citizen by themselves." "If public schooling properly fulfills its task to an adequate level using all the means available to them, then it will certainly have also succeeded in educating capable members of civil society and the state" (p. 9). Since the issue in Switzerland was not specifically to educate merely obedient subjects, but responsible, free citizens, Wettstein thought that this task could never be relegated to a particular school grade or area of instruction. Quite the contrary: "Each individual must personally become an element, a part of the state" (p. 10).

In this respect, it is worth noting that while Wettstein - understandably - based his program for promoting a civic-minded attitude on teaching history, he did not limit the scope of history education to learning about the history of one's own country or one's own people. On the contrary: he suggested assembling a canon of republican heroes and models of virtue from world history, including the heroic figures of the country's own history, who should encourage young people to act in similar (virtuous) ways. History should be taught through pithy examples - Wettstein cites political events like the French Revolution, the Polish struggle for independence, the Indian caste system, as well as republican heroes such as Johann Heinrich Pestalozzi, Benjamin Franklin, George Washington and Hans Konrad Escher von der Linth - as a way to acquaint students with political consciousness and action, and he also assigns a role to instructing geography, singing, mathematics and the visual arts as elements of citizenship education (see e.g. Dahn \& Boser, 2015). Wettstein regarded each of these subjects of study as specifically relevant to citizenship education, with the aim of providing the state and society with a young citizen prepared to "accept and fulfill his position as a citizen and 
an individual with clear eyes, an open mind, and divine inspiration" (p. 18). However, citizenship education did not stop there. "Harvest associations, singing societies, rifle clubs and agricultural societies" and their celebrations, along with the press, will take responsibility for further training during adulthood (Wettstein, 1867, p. 18). Thus, citizenship education was seen as a life-long-learning project, aimed at the nation and the nation-state, but not in an affective reverence for an idea of belonging together or even to the superiority of one's own nation, but rather in a reasonable, knowledgebased emotion towards a particular nation whose achievement was to be found in heroic and philanthropic deeds of ancestors and civilized structures and institutions. Moreover, these were not focused on the canton of Zurich as the state, but included persons and events from "all over the world", their political and moral role model status being their decisive feature.

The oppositional speaker at the School Synod, an equally unidentifiable schoolteacher named Frey from Uster, took a decidedly different position from Wettstein's, proposing an institutional solution: a particular school designed to teach civic knowledge and virtues. His idea of the establishment of such a school of continuing education to cultivate citizens was based on three considerations: first, the existing system of governance, which required a mature, active, and informed citizenry; second, the increasing demands of working life; and third, organizational issues in public schooling at that time (Frey, 1867, p. 4-6). He pointed out that in the interest of increasing general acceptance and promotion of regular school attendance, requirements had been cut back with respect to the overall length of schooling, the regular workload (e.g. number of hours of schooling per week) and the knowledge which was imparted in the compulsory schools. According to Frey, these cutbacks had created a situation in which students left school without a sufficient level of knowledge and understanding to meet economic and social needs, and, as a consequence, the "religiosity and morality of the people" were also at risk (p. 7).

Frey's plan for civic schools called for students to graduate after the age 15 (p. 10) and had to compensate for deficient schooling. He proposed a diverse curriculum which included moral education and practical vocational training, as well as history, geography, civics, health education, singing and gymnastics (p. 10). Frey did not regard the civic school, which he proposed for both girls and boys, as being exclusively a site for civic education, but instead, envisioned broader aims. The civic school "should not [only] be a school for citizenship instruction. Instead, its curriculum should approach the student as a whole in order to foster his mental, moral and physical training. This is its general mission; its specific task is to expand the knowledge which is of greatest use in domestic and working life" (p. 18-19).

In his speech, Frey repeatedly emphasized that he saw civic schools as urgently needed extensions of primary schools, which were to remedy the deficiencies found in graduates of the existing system. His evaluation of the status quo of citizenship education therefore differed widely from Wettstein's, which implies a different approach 
to the topic. According to Frey, these deficiencies specifically included inadequate preparation for vocational life and for the exercise of civic responsibilities, as well as a lack of understanding of moral and religious issues. His speech reveals the close connection between the contemporary understanding of "citizenship education" and "civic and political education," and the central role schools needed to accept in order to fulfill the task. The two speakers agreed about reforming schools to make sure they were successful, but they disagreed about the question whether this mission could be left to the schools alone, or if instead, the schools could or should share it with other institutions.

Thus, all the examples presented here on behalf of the canton of Zurich had in common a certain unease about the quality of civic education. There was also wide agreement on the educational objectives associated with civic education, but there was by no means a consensus about how and with what organizational settings these objectives could be achieved. There seems to have been no such thing as a "Zurich" way of civic or citizenship education. The major point of contention was the question of whether citizenship education could be achieved within the existing school structure, or only outside of it, or with the help of a school specifically set up for this purpose, since, in the eyes of all the authors cited here, civic education did not merely equal knowledge, but was also, or even primarily, a moral stance; and this objective was considered unattainable by mere knowledge transfer.

\section{Civic education in the canton of Vaud}

Unlike the canton of Zurich, the canton of Vaud had already introduced instruction civique (civic education) in primary schools by its very first law in 1834. It also included this subject in the curriculum of its newly established teacher education from the very beginning (1833). But nevertheless, an overview of some statistical data on schools in the canton of Vaud during the 1830s and 1840s, put together in the second half of the nineteenth century, revealed that only around fifteen percent of the students could demonstrate that they had "general knowledge" in "the rights and duties of the citizen" (Archinard, 1870, p. 99). In an examination (spring 1862), grades in the subject of "civics" came in second to last in a ranking of a total of seventeen subjects, on a par with natural sciences but clearly ahead of geometry, civics sat toward the bottom of the list (p. 135). Thus, the outcomes from instruction in civic education were less than impressive, even if the subject and teaching materials related to it had already been part of the primary school curriculum for quite some time. To sum up, it did not matter if civics was taught in schools or not; knowledge about it was - at least in the eyes of its promoters - considered to be rather poor in both cantons (Zurich and Vaud).

In contrast to the canton of Zurich and due to the fact that civic education was a subject in its schools, the canton of Vaud had specific textbooks for these lessons. The teaching material for civic education, the Manuel du Citoyen Vaudois also known as Le Père Thomas (Manual for the citizen of Vaud or The Father Thomas) was published by Gabriel-Antoine Miéville (1766-1852), a lawyer, politician, and publisher, and introduced 
by the Education Council for the use in primary schools (Miéville, [1825] 1846, p. 4; see Dahn-Singh, 2017, p. 113). Miéville's Manual was laid out as a typical textbook of the time, presenting the contents of civic education in a non-school setting. The book tells the story of a fictitious Mister Thomas, who lived in the countryside and whose neighbors sometimes gathered at his house in the evening. Thomas was shaped as the perfect citizen. He "was educated; he had traveled; he loved his country; he understood people and things; and his conversation was a precious wellspring for these good villagers, and they regularly came to draw upon his wise counsel" (p. 5-6). The evening conversations between Thomas and his neighbors were aimed at enlightening them about their duties, making up for their lack of experience, and molding them into "useful citizens" (p. 6). Not only did he teach his neighbors about constitutional law, but he also instructed them about daily life and current prejudices, customs, and practices, thus continuing the popular enlightenment efforts of the $18^{\text {th }}$ century (see Horlacher, 2020, p. 143). These evening conversations were compiled to create a volume with more than twenty chapters, and were rounded off with a statistical-geographical survey of the canton of Vaud (for the relevance of measurement and geography for the $19^{\text {th }}$-century school curricula see Boser, 2016; Winandy, 2019). The content of this textbook is obviously quite similar to what was proposed for civic education in the canton of Zurich. The "perfect" citizen was to be well educated, politically informed, knowledgeable in economics and farming, and a moral personality. In the canton of Vaud, however, there was no question that this educational objective should be achieved within the existing school framework, and with the help of a separate school subject.

A second textbook for civic education in the canton of Vaud was published in 1840 by Louis-François-Frédéric Gauthey (1795-1864), titled Des Droits et des Devoirs des Citoyens Vaudois (On the rights and duties of the citizens of Vaud) and re-published as an expanded second edition four years later. Gauthey worked as a pastor for a year (1819), was employed as a private teacher in England, and from 1834 to 1845 he was head of the Vaud teachers' seminar. After his resignation, which was connected with a political upheaval in the canton, he became head of the denominational Protestant teachers' seminar in the same canton. In the introduction to his book Gauthey made it clear that he viewed civic education as the fulfilment of a legal mandate to educate citizens. He considered that important components of civic education were the explanation of the constitution and the teaching of rights, laws, and duties related to it (Gauthey, [1840] 1844, p. I). In his Rights and Duties, Gauthey emphasized the need to educate citizens, because their lack of knowledge about the political order and political institutions could lead to a host of misunderstandings and erroneous decisions (p. V). However, despite his emphasis on rights and duties, he pointed out clearly that this was not enough to guarantee a "civic" person. "Their spirit, that's true, is enlightened, but their hearts are missing any noble and generous affections, which is mandatory for producing good and great actions" (p. III). Nevertheless, instruction is not useless, yet not sufficient, and must be complemented by affection to the heart. "This is the renouncement to oneself, the commitment to God, to the homeland and 
to humanity, in one term: to the new life. This is the sacred sensation which, combined with the intellectual spirit, forms the real citizen" (p. III). Citizenship education is therefore not only a result of schooling and instruction; it also has a metaphysical or religious aspect, but which also depends on formal teaching to open up the mind for citizenship education.

It is obvious that in the canton of Vaud, the use of schooling as the setting to educate future citizens, was linked to a significantly stronger focus on knowledge about institutions and government than this was the case in the canton of Zurich. Not only was this difference reflected in the development of related teaching materials, but it is already apparent in the wording of the public education law, which specified civic education as a classroom subject to be taught in its own right. Both textbooks demonstrate that knowledge is not enough to elevate the young generation to be citizens. Moral attitudes are important too, even if they are difficult to teach in a formal setting. There was no discussion whatsoever as to the place and extent of civic education in schooling, as the law had set obvious guidelines to be followed. The fact that civic education was a mandatory subject also meant that the need for civic education was, from the beginning, more closely connected to formal schooling than it was in the canton of Zurich.

\section{The same but different?}

These brief examples demonstrate that while the cantons of Zurich and Vaud had similar legal mandates for citizenship education, there were significant differences in their specific formulations and means of implementation. Although Scherr had pointed out the need to improve civic education in the canton of Zurich and had formulated an institutional proposal of how to accomplish this task, his plan was never realized. The topic was frequently debated in various contexts and by various stakeholders, but it was never implemented. By contrast, the canton of Vaud produced teaching materials for civic education, which then became an integral part of the school curriculum - including the allocation of teaching hours and teaching materials. As a result, civic education acquired legitimacy in the canton of Vaud and became firmly anchored in the curriculum, whereas in the canton of Zurich - at least at the primary school level - such legitimacy remained absent and was only introduced in 2018 with the latest curriculum reform (Lehrplan 21), which was designed for most of the German speaking cantons. Here, civic education (as political issues and education to democracy) is not listed as a subject in its own right but as interdisciplinary knowhow and is summarized under the topic of "education for sustainable development".

The question remains open as to what extent the different ways of managing the education of future citizens can be explained by the differences in the cultural, linguistic and historical traditions of the two cantons, and thus as an expression of "German" or "French" ideas about citizenship education, or as an expression of a different sense of identity in the two cantons. It would be an oversimplification to reduce these differences to the mere fact that one canton is French speaking and the other one is German speaking 
or that one canton had had a long tradition of political sovereignty whereas the other was newly founded (for this topic see also the research project "Educating the future citizens: Curriculum and the formation of multilingual societies in Luxembourg and Switzerland"; http://p3.snf.ch/project-141657). However, one may certainly assume that these differences in citizenship education policies cannot be coincidental, but that each set of policies is an expression of a different basic understanding of the purpose and function of education, schooling and the government with regard to citizenship education. In addition, in the case of Switzerland, the nation seems to have been the federal state, not the cantonal state, although "national" emotions were more closely linked to the immediate, i.e. regional or cantonal environments, although these emotions could also be linked to events outside the national borders. Thus, the nation as an educational objective was rather meant as an idea of a federally or cantonally shared community of values (Renan's nation of will), which could be connoted with examples and events that differed from canton to canton for the sake of achieving the common goal.

Nevertheless, what has undoubtedly become clear is that the making of the envisaged citizen is not a "sure-fire success", but the result of various educational means and efforts. The facts that Vaud's teaching materials also contain information of the canton's geographical features, or that Zurich's civics school was primarily intended for low achievement students, clearly show this aspect of "making" of citizenship education. Knowledge about the surrounding area, the pedagogical principle of concentric circles - starting with the closest environment and then broadening the scope -, the high relevance of the local history, flora and fauna in elementary education, are all expressions of the belief that this knowledge also serves to make national identities in the sense of Michael Billig's "banal nationalism" (1995) or - in the words of Ernest Renan - are a "daily referendum" (1882) of one's belonging to a specific political entity as a nation. Schooling as citizenship education is not about the great, national or even nationalistically inspired belief system, but about practicing and accustoming oneself to everyday self-evidences, to the political, social, and economic conditions and traditions; it is about developing and creating ideas of normality, because one has grown up with them and therefore takes them for granted. Given the local conditions of practices, it is therefore not surprising that citizenship education in (the state of) Zurich and in (the state of) Vaud had been formulated differently, although both considered themselves part of the same nation-state, i.e. Switzerland.

\section{Sources}

Archinard, Ch. (1870). Histoire de l'Instruction publique dans le Canton de Vaud. Lausanne: Charles Borgeaud.

Bericht (1850). Bericht über die Verhandlungen der siebenzehnten Schulsynode des Kantons Zürich im Jahr 1850. Zurich: Schulthess'schen Officin.

Bluntschli, J. C. (1837). Herr Seminardirektor und Erziehungsrath Ignaz Theodor Scherr und seine Lehrmittel. Frauenfeld: Beyel. 
Deploige, S. (1898). The Referendum in Switzerland. London: Longmans Green.

Fichte, J. G. ([1808] 2009). Addresses to the German Nation. Cambridge: Cambridge University Press.

Frey, J. C. (1867). Die sozial-bürgerliche und politische Ausbildung unserer Jugend. In Bericht über die Verhandlungen der Zürcherischen Schulsynode (pp. 1-22, appendix III). Zurich: Orell, Füssli \& Compagnie.

Gauthey, L.-F.-F. ([1840] 1844). Des droits et des devoirs des citoyens vaudois ou Essai d'instruction civique. Lausanne: Marc Ducloux.

Gesetz (1832). Gesetz über die Organisation des gesammten Unterrichtswesens im Kanton Zürich, 2. Oktober 1832. In Officielle Sammlung der seit Annahme der Verfassung vom Jahr 1831 erlassenen Gesetze, Beschlüsse und Verordnungen des Eidgenössischen Standes Zürich, Volume 2 (pp. 313-368). Zurich: Staatskanzlei.

Loi (1833). Loi du 10 Décembre 1833, sur l’organisation générale de l'instruction publique. In [Gesetzessammlung] (pp. 1-8). Lausanne: Lausanne: Chancellerie d'Etat.

Loi (1834). Loi du 24 Janvier 1834, sur les écoles publiques primaires. In [Gesetzessammlung] (pp. 9-37). Lausanne: Chancellerie d'Etat.

Lowell, A. L. (1895). The Referendum, and initiative: Their Relation to the Interests of Labor in Switzerland and in America. International Journal of Ethics, 6(1), 51-63. https://doi. org/10.1086/intejethi.6.1.2375621

Macy, J. (1896). The Swiss and Their Politics. American Journal of Sociology, 2(1), 25-42. https://doi.org/10.1086/210579

Miéville, A. ([1825] 1846). Manuel du citoyen vaudois, à l'usage des campagnes et des écoles. Lausanne: Vincent Fils.

Renan, E. (1882). Qu'est-ce qu’une nation? Paris: Calmann Lévy.

Scherr, Th. I. (1837). Beleuchtung der Streitschrift von Dr. Bluntschli gegen den Direktor des Zürcherischen Schullehrer-Seminars. Zurich: Orell, Füssli \& Compagnie.

Scherr, Th. I. (1842). Die Nothwendigkeit einer vollständigen Organisation der allgemeinen Volksschule; hergeleitet aus der zweckwidrigen Beschränkung des Unterrichts auf die Jahre der Kindheit und aus der unzureichenden Fortwirkung der Kinderschule auf ein edleres Volksleben. Winterthur: Druck und Verlag des literarischen Comptoirs.

Wettstein, U. (1867): Die sozial-bürgerliche und politische Ausbildung unserer Jugend. In Bericht über die Verhandlungen der Zürcherischen Schulsynode (pp. 1-19, appendix II). Zurich: Orell, Füssli \& Compagnie.

\section{References}

Anderson, B. (1983). Imagined Communities: reflections on the origin and spread of nationalism. Verso.

Billig, M. (1995). Banal nationalism. Sage.

Boser, L. (2016). Messen ist Wissen. Die Verwendung von Maßen und Gewichten im Primarschulunterricht im 19. Jahrhundert in der Schweiz. In M. Götz, \& M. Vogt (Eds.), Schulwissen für und über Kinder. Beiträge zur historischen Primarschulforschung (pp. 143161). Klinkhardt. 
Boser Hofmann, L. (2017). Nation, Nationalism, Curriculum, and the Making of Citizens. In M. A. Peters (Ed.) Encyclopedia of Educational Philosophy and Theory (pp. 1502-1507). Springer Science+Business Media.

Boser Hofmann, L., \& Dahn-Singh, N. (2017). Une patrie de papier. Représentations du territoire national pour le milieu scolaire dans les cantons de Vaud et Soleure, 1803-1845. traverse. Zeitschrift für Geschichte / Revue d'histoire, 24(1), 19-31. https://doi.org/10.1007/978981-287-588-4 3

Brady, L., \& Kennedy, K. (2007). Curriculum Construction, $3^{\text {nd }}$ Edition. Pearson Education.

Church, C. H., \& Head, R. C. (2013). A Concise History of Switzerland. Cambridge University Press. https://doi.org/10.1017/CBO9781139013765

Criblez, L., \& Hofstetter, R. (1998). Erziehung zur Nation. Nationale Gesinnungsbildung in der Schule des 19. Jahrhunderts. In U. Altermatt, C. Bosshart-Pfluger, \& A. Tanner (Eds.), Die Konstruktion einer Nation. Nation und Nationalisierung in der Schweiz, 18.-20. Jahrhundert (pp. 167-187). Chronos.

Dahn, N., \& Boser, L. (2015). Learning to See the nation-State. History, Geography and Public Schooling in Late $19^{\text {th }}$-Century Switzerland. Bildungsgeschichte. International Journal for the Historiography of Education, 5(1), 41-56.

Dahn-Singh, N. (2017). Autour de l'école: visions de l'éducation politique populaire à l'aube de la Régénération (Vaud, Suisse, 1815-1834). In C. Christen, \& L. Besse (Eds.), Histoire de l'éducation populaire 1815-1945 (pp. 105-116). Presses universitaires du Septentrion. https://doi.org/10.4000/books.septentrion.10951

Dowe, D., Haupt, H.-G., Langewiesche, D., \& Sperber, J. (2000). Europe in 1848. Revolution and Reform. Berghahn Books.

Frey, P. (1953). Die zürcherische Volksschulgesetzgebung 1832-1951. Ein Beitrag zur Geschichte der zürcherischen Volksschule. J. Weiss.

Gotling, N. (2018). Finding national Ideologies in Textbook Historiographies: The Prussian Wars in the historiographical and geohistoriographical narratives of German, Danish, Austrian, and French textbooks, from 1871 to 1939. In S. González, J. Meda, X. Motilla Salas, \& L. Pomante (Eds.), La Práctica Educativa (pp. 127-138). FahrenHouse Ediciones.

Gubler, H. (1933). Die Zürcherische Volksschule von 1831 bis 1845. In Erziehungsrat Kanton Zürich (Ed.), Die Zürcherischen Schulen seit der Regeneration. Band 1: Volksschule und Lehrerbildung 1832-1932 (pp. 101-341). Verlag der Erziehungsdirektion.

Harp, S. (1998). Learning to be Loyal. Primary Schooling as Nation Building in Alsace and Lorraine, 1850-1940. Northern Illinois University Press.

Horlacher, R. (2013). Do Educational Models Impose Standardization? Reading Pestalozzi Historically. In Th. S. Popkewitz (Ed.), Rethinking the History of Education. Transnational Perspectives on Its Questions, Methods, and Knowledge (pp. 135-156). Palgrave Macmillan. https://doi.org/10.1057/9781137000705 7

Horlacher, R. (2017). Politische Bildung als Ausdruck kultureller Überzeugungen? Die Kantone Zürich und Waadt im 19. Jahrhundert im Vergleich. traverse. Zeitschrift für Geschichte / Revue d'histoire, 24(1), 52-62.

Horlacher, R. (2020). Teachers and Teaching. In G. McCulloch (Ed.), A Cultural History of Education. Volume 4: A Cultural History of Education in the Age of Enlightenment (16501800) (pp. 131-145). Bloomsbury. 
Horlacher, R. (2021). Mehr als eine Vorgeschichte. Schule im langen 18. Jahrhundert. In I. Brühwiler, L. Criblez, C. Crotti, M. Helfenberger, M. Hofmann, \& K. Manz (Eds.), Schweizer Bildungsgeschichte - Systementwicklung im 19. und 20. Jahrhundert (in press). Chronos.

Horlacher, R., \& De Vincenti, A. (2013). From Rationalist Autonomy to Scientific Empiricism. A History of Curriculum in Switzerland. In W. F. Pinar (Ed.), International Handbook of Curriculum Research, $2^{\text {nd }}$ Edition (pp. 476-492). Routledge.

Schreiber, C., \& Geisler, N. (2011). "Un lieu protégé“? Staatsbürgerliche Erziehung im Luxemburger Schulsystem im 19. und 20. Jahrhundert. Vierteljahrsschrift für wissenschaftliche Pädagogik, 87(3), 439-456. https://doi.org/10.1163/25890581-087-03-90000004

Tröhler, D. (2007). Die Zürcher Schulsynode: Ein demokratisches Kukucksei in der liberalen Ära Zürichs im 19. Jahrhundert. In C. Crotti, Ph. Gonon, \& W. Herzog (Eds.), Pädagogik und Politik. Historische und aktuelle Perspektiven (pp. 53-68). Haupt.

Tröhler, D. (2008). Verwaltung und Aufsicht der Zürcher Volksschule. In D. Tröhler, \& U. Hardegger (Eds.), Zukunft bilden. Die Geschichte der modernen Zürcher Volksschule (pp. 5468). NZZ.

Tröhler, D. (2011a). The Educationalization of the Modern World. Progress, Passion, and the Protestant Promise of Education. In D. Tröhler, Languages of education: Protestant legacies, national identities, and global aspirations (pp. 22-36). Routledge. https://doi. org/10.4324/9780203828427

Tröhler, D. (2011b). Classical Republicanism, Local Democracy, and Education - The Emergence of the Public School of the Republic of Zurich, 1770-1870. In D. Tröhler, T. S. Popkewitz, \& D. F. Labaree (Eds.) (2011), Schooling and the making of citizens in the long nineteenth century (pp. 153-176). Routledge. https://doi.org/10.4324/9780203818053

Tröhler, D., Popkewitz, Th. S., \& Labaree, D. F. (Eds.) (2011). Schooling and the making of citizens in the long nineteenth Century. Routledge. https://doi.org/10.4324/9780203818053

Westberg, J., Boser, L., \& Brühwiler, I. (Eds.) (2019). School Acts and the Rise of Mass Schooling. Palgrave Macmillan. https://doi.org/10.1007/978-3-030-13570-6

Winandy, J. (2019). From the "known" to the "unknown": Nationalistic "descripction(s) of the earth" as a school subject in the multinational Habsburg Empire. Bildungsgeschichte. International Journal for the Historiography of Education 9(1), 85-99.

\author{
Rebekka Horlacher \\ Institute of Education \\ University of Zurich \\ Freiestrasse 36, 8032 Zürich, Switzerland \\ rhorlach@ife.uzh.ch
}




\section{Građanski odgoj u izgradnji kurikula lojalnoga nacionalnoga građanina: komparativni pogled na Švicarsku}

\section{Sažetak}

Provedba javnoga školovanja obično se razumijeva kao oboje - izraz i sredstvo izgradnje nacije. Formalna organizacija škole, tj. kurikuli, nastavni materijali $i$ primjereno obrazovanje učitelja, tumačena je kao kulturološko-politički sporazum koji proizlazi iz pretpostavljenih nacionalnih uvjerenja o budućnosti određene nacionalne države i njezinih idealnih građana. Prema ovoj postavki, cjelokupna organizacija učenja kurikula može se promatrati kao instrument obrazovanja učenika s ciljem izgradnje lojalnih nacionalnih građana. Od posebnoga interesa je kurikulno područje eksplicitno posvećeno političkom obrazovanju, tj. građanski odgoj. Ovaj rad fokusira se upravo na spomenuto područje i nastavne materijale potrebne za poučavanje o građanskom obrazovanju u nacionalnoj državi koja obuhvaća različite nacije organizirane u kantone, što se ne može odnositi na zajedničku religiju, povijest ili jezik, stoga ni na zajedničku kulturu. Ispitujući dva različita kantona u Švicarskoj, ovaj rad bavi se pitanjem načina na koji se izgradnja nacije može razlikovati unutar okvira jedne nacionalne države.

Ključne riječi: devetnaesto stoljeće; građanski odgoj; izgradnja nacije; povijest školstva; udžbenici. 